\title{
Three Decades of Disarmament, Demobilization, and Reintegration of Ex-Combatants in Africa: Lessons Learned and Challenges Ahead
}

\author{
Anatole Ayissi
}

We are living in dangerous times. Protracted conflicts are causing unspeakable human suffering. Armed groups are proliferating, equipped with a vast array of weapons. As armed conflicts grow more deadly, destructive and complex, we need a new focus on disarmament that saves lives. ${ }^{1}$

\section{INTRODUCTION}

This chapter is an analysis of three decades of efforts to disarm, demobilize, and reintegrate former combatants as part of conflict resolution

This chapter represents the personal views of the author.
A. Ayissi $(\bowtie)$
United Nations Regional Office for Central Africa, Libreville, Gabon e-mail: anatole.ayissi@usa.net
(C) The Author(s) 2021
T. McNamee and M. Muyangwa (eds.), The State of Peacebuilding in Africa, https://doi.org/10.1007/978-3-030-46636-7_9 
and post-conflict peace consolidation, particularly in contexts of peacekeeping operations carried out by the United Nations. The chapter reviews the evolution of disarmament, demobilization, and reintegration (DDR) programs in Africa over the last 30 years, highlighting, in particular, trends and challenges relating to their implementation as well as the lessons learned and the best practices recorded. It concludes with a few observations on the future of DDR in Africa, as well as practical recommendations to policymakers and practitioners, taking expressly into consideration the prevalent conflict landscape in Africa, made up of "the continuing volatility of local conflict dynamics," 2 which is aggravated by the mounting scourge of violent extremism, terrorism, ${ }^{3}$ and the "democratization of armed violence" in a number of countries and areas.

DDR is defined as an operation that consists of the assembly and cantonment of ex-combatants, consistent with the provisions of a peace agreement, with a view to collecting their weapons, disbanding their formal military framework, and assisting them in reintegrating into society, either as civilians or formal members of national armed or security (e.g., national police, gendarmerie) forces. ${ }^{4}$

\section{Disarmament, Demobilization, AND Reintegration in Africa: Contexts And Contents}

The "Disarmament, Demobilization, Reintegration, and Rehabilitation" $\left(D D R R^{5}\right)$ of ex-combatants has emerged as a major pillar for post-conflict peace consolidation in Africa. For a number of peace processes and operations on the continent, the quality of DDR implementation ranks high on the list of the criteria against which the probability of a country recovering from crisis to relapse into violence is assessed. As stated by Colonel (rtd.) Prosper Nzekani Zena of the Democratic Republic of the Congo (DRC), experience shows that "incomplete or poorly conceived disarmament, demobilization, and reintegration (DDR) initiatives have been key factors to high rates of conflict relapse in Africa." 6 Successfully implemented DDR programs, however, give the stronger chances to conflict resolution and post-conflict peace. Indeed, the rationale behind the need to respond urgently to the challenge of ex-combatants after conflict is that "DDR programs are essential in helping to prevent the recurrence of war in post-conflict situations." 7

An overview of DDR programs in Africa over the last three decades shows that these programs have been carried out in two broad crisis 
contexts. Some DDR programs are initiated as part of efforts toward addressing a security crisis provoked by inadequacies and deficits in the national security sector, with a view to implementing a national security sector reform (SSR) strategy. Though a significant number of African countries have carried out such programs, especially southern and West African countries, experience shows that the vast majority of DDR programs in Africa are, instead, carried out in the context of the implementation of a peace agreement, generally concluded between the protagonists of a civil war.

When adopting its standards and operational rules pertaining to the implementation of DDR programs ten years ago, the United Nations took note of the growing demand for DDR, stressing that especially since the late 1980s, the international community had "increasingly been called upon to support the implementation of DDR programs in countries emerging from conflict," 8 including African countries in particular. Indeed, as of 2019, over two-thirds of the 54 African countries have implemented DDR programs in the context of a peace process, often with the assistance of the United Nations. ${ }^{9}$

\section{Thirty Years of Disarmament, Demobilization, ANd Reintegration in Africa: Issues, TRENDS AND LesSONS LEARNED}

One of the major lessons learned from these programs is that the fate of DDR is shaped by changes and evolutions in UN peace operations. In a keynote address delivered during a meeting on DDR in Abidjan, Côte d'Ivoire in 2017, the UN High Representative for Disarmament Affairs, Izumi Nakamitsu, emphasized this connection between "the nature of DDR operations and peacekeeping." 10 She recalled "how crucial the disarmament, demobilization and reintegration processes are to sustaining peace." She stressed that "over the past three decades, DDR has become an integral part of peace operations across the globe [and] has played a key role in violence prevention, stabilization and support to political processes." She noted that "this crucial contribution to sustaining peace is manifested in successful DDR programs, as witnessed in Central America, Angola, Sierra Leone, Liberia, and-of course-Côte d'Ivoire."ll 


\section{Africa, a Major Host of Disarmament, Demobilization, and Reintegration Programs}

The fact that four out of the five examples cited above are from Africa is not a coincidence. Since the inception of the first major United Nations DDR programs in Central America about three decades ago, ${ }^{12}$ the African continent has been the most important host for DDR programs. ${ }^{13}$ In 2006, the Secretary-General of the United Nations revealed that between February 2000 and March 2006, "six peacekeeping operations have included disarmament, demobilization and reintegration as part of their mandate," among which five were in Africa: the United Nations Organization Mission in the Democratic Republic of the Congo (MONUSCO); the United Nations Mission in Liberia (UNMIL); the United Nations Operation in Côte d'Ivoire (UNOCI); the United Nations Operation in Burundi (ONUB); and the United Nations Mission in Sudan (UNMIS). ${ }^{14}$ Three years later, in 2009, the World Bank estimated that two-thirds of the over 30 countries where DDR programs have been implemented over the last 20 years are in Africa. ${ }^{15}$

As of 2020, there were 13 peacekeeping operations active globally, many with a DDR component. Half of these operations are in Africa: Western Sahara, the Central African Republic, Mali, the Democratic Republic of the Congo, Darfur, Abyei (the border between Sudan and South Sudan), and South Sudan. ${ }^{16}$ DDR is a major priority for all of these operations. For many of them, DDR has proved to be a strong imperative for a timely and efficient implementation of signed peace agreements.

From the quantitative standpoint, hundreds of thousands of excombatants have been disarmed and demobilized in Africa over the last decades, thus contributing significantly to increasing chances for sustainable peace and recovery after crises. ${ }^{17}$ Overall, available data show that close to one million ex-combatants have gone through formal DDR programs since the late 1980s. In the Democratic Republic of the Congo alone, 209,605 ex-combatants had gone through DDR by March 2011, 18 while over 100,000 ex-combatants were disarmed, demobilized, and sent back to regular life at the end of the civil war in Liberia, and about 93,000 ex-combatants were the subject of DDR in Mozambique. ${ }^{19}$ In addition, 72,490 and 80,000 ex-combatants underwent DDR in Sierra Leone and Angola, respectively. ${ }^{20}$ The most recently concluded DDR program in Africa was in Côte d'Ivoire, where a total of 69,505 ex-combatants were disarmed and demobilized between October 2012 and June 2015. Thus, in terms of numbers, DDR has achieved tremendous success in Africa. 
This is good news for peace and recovery, since the "process of disarmament, demobilization and reintegration has repeatedly proved to be vital to stabilizing a post-conflict situation" and "to reducing the likelihood of renewed violence." 21

However, the analysis in the next section will show that this success has to be appreciated against the background of a great deficit of qualitative outcomes in many DDR programs. In practice, many DDR programs have essentially been about the "DD," while the most critical "R" generally remains unaddressed. Many DDR programs have also suffered a lack credibility stemming from the inherent fragility of the peace agreements which gave rise to them. Yet when done well, the evidence is clear that DDR can "make a key contribution to strengthening confidence between former factions and enhancing the momentum toward stability."22

\section{Africa as a "Living Laboratory"23 for Disarmament, Demobilization, and Reintegration}

Africa has also proved to be an important "laboratory" for DDR experiments, in particular in the context of rapidly changing post-Cold War conflict settings. In the 2000s, as new conflict landscapes were emerging in Africa-and the rest of the world ${ }^{24}$ - many DDR programs increasingly faced difficulties and could not be implemented as provided for in peace agreements. The then Secretary-General of the United Nations, in a report to the General Assembly, noted that "while the scale, complexity, scope and type of the United Nations work in disarmament, demobilization and reintegration have changed, our means of planning and implementing such operations have not." He warned that this has ultimately led "at worst $[\ldots]$ to disillusioned ex-combatants returning to arms." The resurgence of armed violence amidst peace processes in these countries led the Secretary-General to recognize that "the narrow focus on short-term security goals," when it comes to implementing DDR programs, was inefficient, if not counterproductive, for post-conflict recovery and peace consolidation. He recommended "to capture systematically lessons learned from previous disarmament, demobilization and reintegration programs and to ensure that the lessons are rigorously applied in future operations." 25 The exceptionally tough challenges that UN peacekeeping operations met in Africa, including in places such as Sierra Leone and Somalia, greatly informed the thinking that followed 
these recommendations and which, in 2010, led the UN to develop "the 'second generation' DDR." 26

A major emerging trend in the "transformation of conflict" taken into consideration when crafting the second generation of DDR was the mounting threat of what Jairo Munive and Finn Stepputat called "Armed Non-Statutory Actors" (ANSAs), i.e., those spoilers who were neither part of national armed forces nor "non-state" (rebel) armed groups formally part of the process of implementation of peace agreements. An ANSA was defined as an "organized group with a basic structure of command operating outside state control that uses force, or the threat of force, to achieve its objectives [...], ranging from insurgent armies and militias to vigilantes and urban gangs, exercise some degree of control over territory and populations, and they may develop levels of organization similar to or even surpassing that of statutory armies."27

In line with this analysis, when crafting the second generation of DDR, Munive and Stepputat underscored that while "in the 1990s, international DDR programs were used mostly to deal with statutory and insurgent armies following peace accords to which the warring parties were signatories, since then, however, other types of armed actors, such as militias, have grown in importance and have influenced the stability of governments and the security of civilian populations by demonstrating a high degree of flexibility and [...] adaptability to shifting circumstances." 28 The ongoing conflict in the eastern DRC, which has now lasted over 20 years, is one of the most emblematic illustrations of this situation.

As a "response to the shifting anatomy of armed conflict," the DDR concept was radically reconfigured, especially "to deal with armed groups while conflict is still ongoing and without a negotiated peace accord being in place," and also to address "situations of armed conflict that involve hybrid forms of violence as well as a range of armed actors that control, or influence significantly, populations and territories, without being part of peace negotiations or under direct state control," as is the case, for instance, in the Democratic Republic of the Congo (DRC), Sudan, and Somalia, where "militias have become one of the main agents of political violence." 29

One of the reasons behind the advent of the second generation of DDR was to "contribute to a secure environment and help build the foundation for longer-term peacebuilding." But more than a decade after the adoption of the UN's DDR standards and the advent of the second generation of DDR, there is still a strong sense in Africa that many 
conflicts/crises on the continent will not be solved unless the international community changes how peacekeeping and DDR are done. To highlight only a few examples:

i. In January 1999, in Sierra Leone, a failed peace and DDR process led to armed rebels from the Revolutionary United Front (RUF) launching a brutal attack on Freetown, the capital city. By the time the peace operation regained control of the situation, more than 5,000 people had been killed. ${ }^{30}$

ii. In the DRC, where more than 200,000 ex-combatants were disarmed and demobilized in the early 2010s, dozens of armed groups were still active in the eastern part of the country at the end of the decade, resulting in thousands of deaths annually over the period. More than two million people were newly displaced in 2017 and 2018 alone. $^{31}$

iii. The Central African Republic (CAR) has hosted more than 13 international or regional peace missions over the last 20 years, ${ }^{32}$ and as many, if not more, DDR programs. Yet as of early 2019 , over 80 percent of the country was controlled by armed groups. ${ }^{33}$

iv. For many years, the UN peacekeeping mission in Côte d'Ivoire was highly supportive of DDR endeavors deployed by the government and much was accomplished. On June 28, 2017, the Secretary-General of the United Nations welcomed "the closure of the United Nations Operation in Côte d'Ivoire (UNOCI) [scheduled] on 30 June 2017, after having successfully achieved its mandate." 34 Unfortunately, three months later, supposedly disarmed ex-combatants launched a series of attacks or mutinies (for those reintegrated in the national armed forces) in Abidjan and other localities of Côte d'Ivoire, threatening to "set the country on fire," claiming that the government had yet "to pay" the full amount of money promised to each combatant as a component of the DDR package. ${ }^{35}$ This was the second time in six months that Ivorian ex-combatants had rebelled against state authority and wreaked havoc in their respective neighborhoods.

It is worth noting that in all of these cases, civilian populations in the affected communities were the first and main victims of the recurring waves of DDR-related violence. 


\section{From Combatant-Focused to Community-Based Disarmament, Demobilization, AND Reintegration}

There is a major lesson that emerges from these and other DDR experiences $^{36}$ : the most effective way to guarantee the success and sustainability of DDR programs is to make sure that these programs serve not only excombatants, but also, and above all, all the populations and communities affected by violent conflict, including the most vulnerable among them. As such, as many African countries emerging from crisis continue to deal with the impact of armed violence on civilian populations, it has become common practice to assess the efficiency of a DDR project holistically: how well has it served the whole community that has been devastated by armed conflict? Fifteen years after the very first DDR programs were launched on the continent, Africa Renewal, a publication of the United Nations that focuses on African economic and social issues, recalled that this concern had become one of the most pressing challenges that DDR programs faced in the majority of the countries in which they were being implemented. In a special issue, released in October 2005, which undertook a comprehensive assessment of DDR implementation programs, a wide range of practitioners and academics spoke about their respective experiences with DDR. The majority of them deplored the fact that "because of their specific mandates [which focus on ex-combatants], most DDR programs concentrate on ex-combatants, and less on the communities to which they will return." They recommended that these projects "should do more to help broader community recovery." 37

Five years earlier, in 2000, as the counterproductive effects of excombatant-focused DDR were being increasingly felt amidst countries and communities recovering from conflict, Victor Odame Asiedu published a PhD dissertation entitled "A Study of How Communitybased Approach to Disarmament, Demobilization, and Reintegration (DDR) can Contribute More Effectively to Peacebuilding" in Africa. ${ }^{38}$ His analysis highlighted the fact that "whilst the use of DDR continues to grow, it has been criticized for its focus on ex-combatants rather than communities." 39 He concluded that a major consequence of such narrowly focused DDR is that it "sometimes creates divisions among community members and strains the entire peacebuilding process." 40 Asiedu further observed that "in view of this limited approach to DDR, academics and practitioners alike are increasingly arguing for a community-based (CB) approach, especially during the reintegration 
process, as a way of addressing resentment among community members, which impedes more effective peacebuilding." 41 His analysis echoed the work of two experts from the Danish Institute for International Studies, who argued that DDR should "comprise communal development projects in order to diminish resentment from non-combatants in the 'home communities." 42

The initial DDR programs implemented in African countries emerging from armed conflict were exclusively intended for "those bearing arms." These "weapons-users" were considered and treated as a distinctly specific group, different from the rest of the community. Consequently, instead of strengthening social cohesion after conflict, DDR programs became one of the most divisive factors in communities affected by armed conflict, re-fueling conditions that led to armed violence. The disruptive effects of DDR were both domestic and cross-border/regional.

On the domestic side, DDR packages offered to ex-combatants included, among other features, in-kind compensation, free vocational training, and resources for income-generating projects. In addition, each ex-combatant was provided with a significant amount of cash; for instance, in Liberia it was US $\$ 300$ per ex-combatant, and in Côte d'Ivoire, US $\$ 1,000$. In the post-war environment of acute scarcity and dire poverty, in which the vast majority of peoples live on less than half a dollar a day, these payments were relatively generous. In the eyes of those populations excluded from DDR programs because they neither carried guns nor killed people, such a comparatively large amount of money offered to ex-combatants was morally and economically unjust. They viewed ex-combatants as the privileged few who benefited from the tragedy of war. This situation generated widespread frustration and anger, further complicating the relationship between returning ex-combatants, the civilian population, and the international community that funded and implemented DDR programs. In some cases, international partners were accused of "rewarding violence." The challenges raised here mirror those highlighted by Bigombe in her case studies of DDR in Uganda and Burundi in this volume.

On the regional side, combatant-focused DDR also had important regional and cross-border consequences. In countries where armed conflicts are recurrent, one of the grimmest effects of combatant-focused DDR was that every recurring wave of armed violence generated an increasing number of people, especially the young, taking up arms and 
fighting, some with the hope of benefiting from post-crisis DDR packages. Hence, ironically, DDR became yet another incentive to violence, especially in those parts of Africa where armed conflicts easily spread across state borders. The cross-border impact of violence culminated in a phenomenon the United Nations calls "foreign combatants." Their implications for DDR are significant.

"Foreign combatants" are nationals from a country crossing the border to participate in an armed conflict in another country, generally for political or economic reasons. In terms of the rules governing armed conflict, African "foreign combatants"-also called "negative forces" in the DRC - are a distinctive type of "soldiers of fortune" with a gray legal status between a "mercenary" and a "transnational criminal." For instance, while many young Sierra Leoneans fought in the civil war in Liberia, there are also many young Liberians who were recruited by Sierra Leonean rebel groups to fight in Sierra Leone; likewise, nationals from Chad fought in the civil war in the CAR, while many Sudanese "foreign combatants" are found in both Chad and the CAR. ${ }^{43}$ The situation in the DRC, where spoilers of one kind or another are pervasive in the eastern part of the country, illustrates how DDR can serve to incentivize the regionalization of both armed conflict and armed combatants. Many ex-combatants could easily cross state borders and fight multiple wars, thus benefiting from DDR packages from two to three countries as happened during the wars that raged in the West African Mano River Basin (Liberia, Sierra Leone, and Côte d'Ivoire) between December 1989 and April 2011.

DDR experts and practitioners have learned from these experiences. Today's DDR programs enable countries to foster community-based development, social cohesion, post-conflict reconciliation, and peacebuilding. According to the UN's new Integrated Disarmament, Demobilization and Reintegration Standards (IDDRS), such community-based DDR lays the groundwork "for safeguarding and sustaining the communities" in which ex-combatants "can live as law-abiding citizens, while building national capacity for long-term peace, security, and development." 44

Over the last decade, many governmental and non-governmental actors who committed to rebuilding peace in African countries recovering from armed conflicts have been consistently adjusting their DDR programs in the field with the objective of addressing the concerns and priorities of local communities. This is, for instance, the case for the 
United States Agency for International Development (USAID) and its "Community-Focused Reintegration" (CFR) project, ${ }^{45}$ which takes into consideration the need "to promote reintegration by creating a safe environment in which elements of divided communities could interact." Likewise, Pax Christi, a Rome-based NGO helping communities affected by armed crises to respond to the challenging issue of transitional justice, has crafted a "Community Based Reintegration and Security" (CBRS) program that recommends that DDR efforts should "take root at local levels, which is essential to their legitimacy and sustainability."

In order to disseminate knowledge and build the skills of practitioners in the area of community-based DDR, the United Nations, in synergy with other partners, has developed a specialized training course on "Community-Based Reintegration and Security (CBRS) for practitioners." The course teaches "an innovative approach for more comprehensive context and community-driven reintegration, integration, resilience, and community security programming," focusing in particular on "how community-based economic development can increase economic opportunities" for both ex-combatants and the larger community, thus "encouraging acceptance amidst those hosting communities" of ex-combatants. ${ }^{46}$ The course also explores new ways to design more "gender responsive programming." 47 In terms of information and experience sharing, the course offers the opportunity to bring together "experienced practitioners from around the world to learn about cuttingedge approaches and theories, to share experience, and develop their skills to effectively plan and deliver community-based reintegration and security programmes." 48

\section{Disarmament, Demobilization, ANd Reintegration in Africa: The Achilles Heel, and the Iron Rules}

\section{The Achilles Heel: The Challenge of Incomplete Reintegration}

DDR is a hugely complex operation, especially in Africa's conflict settings. One of the early lessons to emerge from the UN's first comprehensive review of DDR on the continent is that "the disarmament, demobilization and in particular the reintegration processes extend beyond the life of a peacekeeping operation." 49 Nearly 15 years after that assessment, it seems clearer still that whether a peacekeeping operation concludes its mandate successfully or not, DDR should continue regardless. 
The good news is that thinking on DDR in the UN and other institutions is not static. It is, in fact, almost constantly under scrutiny, with considerable attention given to reforming its practice to align with rapidly evolving conflict dynamics in Africa. As the then-Secretary-General of the United Nations observed, "While the scale, complexity, scope and type of the United Nations work in disarmament, demobilization and reintegration have changed, our means of planning and implementing such operations have not." 50

The implementation of "Integrated DDR Standards" (IDDRS) in 2006 greatly improved cooperation and synergies among the various UN and non-UN actors in charge of the implementation of DDR. Nearly 15 years after the adoption of the IDDRS, the transformation of conflictsespecially in the CAR, the DRC, the Sahel, the Great Lakes region, and the Horn of Africa-continues to challenge our assumptions and hypotheses. The most recent reconceptualization by the UN on DDR puts new emphasis on violent extremism and threats posed by terrorism ${ }^{51}$; as well as what the Rift Valley Institute calls "the democratization of militarized politics" (the case of the eastern DRC and the Great Lakes region). ${ }^{52}$

A major qualitative improvement in DDR practice is how women and female ex-combatants are now central considerations, manifest in the "Standard Operating Procedures on Gender and DDR," where once they were all but ignored. ${ }^{53}$ In the same vein, the specific situation of ex-child combatants, notably, what the UN Secretary-General calls "the moral imperative to disarm children," is also duly considered during the implementation of DDR programs.

The prospects for conflict and violence in Africa show that DDR will continue to be a key parameter for conflict resolution and peacemaking in the coming years. Many African countries-Mozambique, Sierra Leone, Liberia, Côte d'Ivoire amongst them-previously in widespread conflict face challenges from significant "remnants of war" comprising nondisarmed or inadequately demobilized ex-combatants. In these countries, like in the vast majority of Africa's conflict-affected societies, the "R" ("Reintegration") remains the Achilles heel of DDR programs. Although ex-combatants are most often fully disarmed and demobilized, those who are sustainably "reintegrated" are a minority.

There is, therefore, a need to boost the "reintegration" component of DDR with more resources, not only to address the concerns of ex-combatants, but also to enhance economic growth, create jobs, 
and open more opportunities for business and entrepreneurship. ${ }^{54}$ The funding trend is moving in the opposite direction, however. Budgets for many peace operations, especially for reintegration efforts, have been reduced. This is most notable for MONUSCO, one of the UN's longest and biggest missions. ${ }^{55}$ One response to the conundrum of growing demand but dwindling resources would be to strengthen Africa's ownership of DDR programs, endowing regional institutions (African Union and regional economic communities) with adequate institutional capacities, expertise, and resources. This is a path that the African Union has been following, with its Disarmament, Demobilization and Reintegration Capacity Program (DDRCP), initiated in 2012, which aims "to strengthen the capacities within the AU, its Member States and regional partners, to support national and regional DDR initiatives on the continent." 56

The AU DDRCP program, which, if adequately handled, could become the best hope for the future of DDR in Africa, comprises three fundamental objectives:

i. Institutionalize DDR capacities within the African Union;

ii. establish an AU DDR Resource and Research Centre; and,

iii. facilitate $\mathrm{AU}$ engagement and assistance to DDR activities of member states. ${ }^{57}$

The AU DDRCP is strongly supported by the AU's major partners, including, among others, the World Bank and the United Nations. ${ }^{58}$

\section{CONCLUSION}

In May of 2018, UN Secretary-General Antonio Guterres outlined the new context of global conflict, arguing that many populations continue to live "in dangerous times, protracted conflicts are causing unspeakable human suffering. Armed groups are proliferating, equipped with a vast array of weapons"; as these conflicts "grow more deadly, destructive and complex, we need a new focus on disarmament that saves lives." 59 The United Nations General Assembly, alarmed by this deteriorating situation, has thus requested the Secretary-General "to explore options for strengthening the United Nations-World Bank collaboration ${ }^{60}$ in conflict-affected countries" and create "an enabling environment for economic growth, 
foreign investment and job creation, and in the mobilization and effective use of domestic resources, in line with national priorities and underscored by the principle of national ownership."61 Relating specifically to DDR, such an initiative could be considered in the context of Sustainable Development Goal 16, whereby African and world leaders pledged "to foster peaceful, just and inclusive societies which are free from fear and violence. There can be no sustainable development without peace and no peace without sustainable development." The African Union, which Guterres considers as the United Nations' "most relevant partner in peace and security in the world" 62 should play a key role in this global partnership for sustainable DDR in those African countries and regions ${ }^{63}$ recovering from or affected by the crisis of the proliferation of armed groups and weapons of war.

\section{Key Recommendations: Three Iron Rules}

The following policy recommendations are inspired by analyses and action-points relating to post-crisis recovery and sustainable peacebuilding contained in recent relevant reports, policy papers, and strategic frameworks from the African Union, the United Nations, the World Bank, and the African Development Bank. ${ }^{64}$ The recommendations are crafted as practical action-points leading to more effective and sustainable forms of peacemaking and crisis recovery measures, including in particular, DDR. ${ }^{65}$

\section{Secure adequate and timely funding for Disarmament, Demobi-} lization, and Reintegration. The need for adequate, timely, and predictable funding, especially for the "reintegration" component, remains the Achilles heel of DDR programs. There is, therefore, need to guarantee reliable, predictable, and sustainable sources of funding for the "reintegration" component to reduce the risk for countries recovering from crisis to relapse into violence. ${ }^{66}$ The difficulties of securing funding for the reintegration of demobilized ex-combatants are partly explained by the fact that while the disarmament/demobilization of ex-combatants are accounted for in the assessed budget for peacekeeping operations, the reintegration of disarmed and demobilized combatants relies on voluntary funding. Unfortunately, experience shows only part of the funds pledged by donors is disbursed in an effective manner. Moreover, even when 
pledges materialize, "In most cases there is a six- to eight-month gap from the time funds are pledged to the time they are available for use. The failure to follow through on promises made due to the lack of reliable funding could result in violence, re-recruitment of those already disarmed into local and regional conflicts, and a breakdown of the peace process." 67

2. Address the paradox of successful peacekeeping operations followed by collapse in countries recovering from crisis. There is need to bridge the gap between short-term emergency funding for peace and longer-term investment financing for economic and social development, including job-creation, income-generating activities, and business opportunities for youth and ex-combatants. Many countries where the United Nations has successfully completed a peacekeeping operation continue to be threatened by "remnants of war," often poorly reintegrated ex-combatants. Since DDR extends "beyond the life of a peacekeeping operation," it is critical for the viability of the peace and crisis recovery process to continue to strengthen relevant national capacities. DDR requires human and financial resources sufficient for a successful transition from emergency peacekeeping and humanitarian action to financing economic and social development activities that create jobs and provide real alternatives to war for ex-combatants and youth. Among others, the United Nations' Peacebuilding Fund, which was established precisely to "assist countries in their transition from war to peace" and prevent state collapse and the slide to armed conflict, ${ }^{68}$ should be endowed with adequate resources to assist countries "in the transition from the immediate post-conflict phase to longer-term reconstruction and development." 69

3. Frame and develop a regional response to the challenges of disarmament, demobilization, and reintegration in Africa. The African Union, within the framework of its "Silencing the Guns in Africa"70 initiative, should work in partnership with the UN, the World Bank, ${ }^{71}$ the African Development Bank, and any other relevant stakeholders, to frame a regional response to the challenge of DDR in African post-conflict countries, focusing on peacebuilding and Sustainable Development Goal 16. ${ }^{72}$ Though the global impact of armed conflict has lessened, available data show that "more countries have recently experienced violent conflict than at any time in nearly three decades."73 Many of the ongoing conflicts are in Africa, 
which hosts 40 percent of all United Nations peacekeeping operations in the world. "With a decline in civil wars ending in military victory," Sebastian von Eisendel cautions, "the conflict relapse rate has increased" on the continent. ${ }^{74}$

\section{Notes}

1. Antonio Guterres, An Agenda for Disarmament, United Nations, New York, 2018.

2. Judith Verweijen and Claude Iguma Wakenge, "Understanding Armed Group Proliferation in the Eastern Congo," PSRP Briefing Paper 7, Rift Valley Institute, December 2015.

3. Jasmine-Kim Westendorf, Why Peace Processes Fail: Negotiating Insecurity After Civil War (Boulder, CO: Lynne Rienner, 2015).

4. United Nations, "The Role of United Nations Peacekeeping in Disarmament, Demobilization and Reintegration," Report of the SecretaryGeneral to the Security Council, February 11, 2000 (S/2000/101); United Nations, "Disarmament, Demobilization and Reintegration," Report of the Secretary-General to the General Assembly, March 2, 2006 (A/60/705); See also Stina Torjesen, "The Political Economy of Disarmament, Demobilization and Reintegration," Paper 709, Norwegian Institute of International Affairs, 2006, https://www.files.ethz.ch/ isn $/ 27897 / 709$.pdf.

5. For practical purposes, this chapter uses the shorter acronym: "DDR." "Rehabilitation" is included because successful reintegration requires providing ex-combatants with social services, educational opportunities, and work so that they can progressively reclaim their legitimate place and status in society as human beings and citizens.

6. Prosper Nzekani Zena, "The Lessons and Limits of DDR in Africa," Africa Security Brief, Africa Center for Strategic Studies, Washington, DC, 2013.

7. Jairo Munive and Finn Stepputat, "Rethinking Disarmament, Demobilization and Reintegration Programs," International Journal of Security o Development, Stability: International Journal of Security \& Development 4, no. 1 (2015): 1-13, 48, https://www.stabilityjournal.org/articles/10. $5334 /$ sta.go/.

8. The Inter-Agency Working Group (IAWG) on DDR, Integrated Disarmament, Demobilization and Reintegration Standards (New York: United Nations, December 2006).

9. Some of the countries where DDR has either been implemented or is being implemented or envisaged are: Angola, Burundi, Côte d'Ivoire, the Central African Republic, Chad, Congo, Democratic Republic of 
the Congo, Guinea Bissau, Liberia, Mali, Mozambique, Namibia, Niger, Rwanda, Sierra Leone, Somalia, Sudan, Uganda, South Africa, and Zimbabwe. See Zena, "The Lessons and Limits of DDR in Africa"; W. Andy Knight, "Disarmament, Demobilization, and Reintegration and Post-conflict Peacebuilding in Africa: An Overview," African Security, 2008, https://www.tandfonline.com/doi/pdf/10.1080/193622008022 85757? needAccess=true.

10. Remarks by the High Representative for Disarmament Affairs, Ms. Izumi Nakamitsu, on behalf of the Secretary-General of the United Nations, "DDR High-Level Roundtable: Tenth Anniversary of the Integrated DDR Standards And the Experience of Côte d'Ivoire," New York, June 19, 2017.

11. Remarks by High Representative for Disarmament Affairs, Ms. Izumi Nakamitsu.

12. The very first major DDR program was carried out in the context of the United Nations Observer Group in Central America (ONUCA), authorized by the Security Council in 1989: see Rainer Grote, "The United Nations and the Establishment of a New Model of Governance for Central America: the Case of Guatemala," in Max Planck Yearbook of United Nations Law Volume 2, Armin von Bogdandy and Rüdiger Wolfrum (eds.) (Max Planck Institute, 1998).

13. United Nations, DDR in Peace Operations: A Retrospective (New York: Department of Peacekeeping Operations, 2010).

14. The sixth was the United Nations Stabilization Mission in Haiti (MINUSTAH); see United Nations, "Disarmament, Demobilization and Reintegration."

15. World Bank, "Disarmament, Demobilization and Reintegration," Social Development Department, February 2009, 1, http://siteresources.wor ldbank.org/EXTSOCIALDEVELOPMENT/Resources/244362-116410 7274725/DDRFinal3-print.pdf.

16. The rest comprises Haiti, Cyprus, Golan, Lebanon, Kosovo, India and Pakistan, and Middle East. See: United Nations, Department of Peacekeeping Operations, "Current Peacekeeping Operations," https://peacek eeping.un.org/en/where-we-operate.

17. Munive and Stepputat, "Rethinking Disarmament, Demobilization and Reintegration Programs."

18. World Bank, "Demobilization and Reintegration in the Democratic Republic of Congo (DRC)," March 11, 2013, http://www.worldbank. org/en/results/2013/03/11/demobilization-and-reintegration-in-thedemocratic-republic-of-congo.

19. Guy Lamb, "DDR 20 Years Later. Historical Review of the Long-term Impact of Post-independence DDR in Southern Africa," World Bank, June 2013. 
20. Christina Solomon and Jeremy Ginifer, "Disarmament, Demobilization and Reintegration in Sierra Leone," Center for International Cooperation, University of Bradford, July 2008.

21. United Nations, "The Role of United Nations Peacekeeping in Disarmament, Demobilization and Reintegration."

22. Ibid.

23. Expression borrowed from Helen Tilley, Africa as a Living Laboratory: Empire, Development and the Problem of Scientific Knowledge: 1870-1950 (Chicago: University of Chicago Press, 2011).

24. Martin Van Creveld, The Transformation of War (New York: The Free Press, 1991).

25. United Nations, "Disarmament, Demobilization and Reintegration," Report of the Secretary-General to the General Assembly of the United Nations, March 2, 2006 (A/60/705).

26. United Nations, "Second Generation Disarmament, Demobilization and Reintegration (DDR) Practices in Peace Operations a Contribution to the New Horizon Discussion on Challenges and Opportunities for UN Peacekeeping," Department of Peacekeeping Operations (DPKO), New York, 2010.

27. Munive and Stepputat, "Rethinking Disarmament, Demobilization and Reintegration Programs."

28. Ibid.; Robert Muggah (ed.), Security and Post-conflict Reconstruction: Dealing with Fighters in the Aftermath of War (New York: Routledge, 2009); J. Schulhofer-Wohl and N. Sambanis, Disarmament, Demobilization, and Reintegration Programs and Civil War Recurrence: An Assessment, Research Report, Folke Bernadotte Academy, 2010, https:// faculty.virginia.edu/j.sw/uploads/research/Disarmament,\%20Demobiliza tion,\%20Reintegration\%20Programs_\%20An\%20Assessment.pdf.

29. Munive and Stepputat, "Rethinking Disarmament, Demobilization and Reintegration Programs."

30. Richard McHugh, "Revolutionary United Front," Encyclopaedia Brittanica, May 1, 2016, https://www.britannica.com/topic/RevolutionaryUnited-Front.

31. "DRC Conflict: Facts, FAQs, and How to Help," World Vision, July 23, 2019, https://www.worldvision.org/disaster-relief-news-stories/drcconflict-facts.

32. The very first peace mission in the Central African Republic was established in 1997 by African Heads of States, namely: The Inter-African Mission to Monitor the Implementation of the Bangui Agreements (MISAB). Then on March 27, 1998, the Security Council decided "To Establish a United Nations Mission in the Central African Republic (MINURCA) with Effect from 15 April 1998"; see Security Council resolution 1159, March 27, 1998. 
33. "CAR: 14 Armed Groups for One Poor Country," AFP, February 6, 2019, https://www.news24.com/Africa/News/car-14-armed-groupsfor-one-poor-country-20190206.

34. United Nations, "Statement Attributable to the Spokesman for the Secretary-General on the Closure of the United Nations Operation in Côte d'Ivoire," New York, June 28, 2017, https://www.un.org/sg/en/ content/sg/statement/2017-06-28/statement-attributable-spokesmansecretary-general-closure-united.

35. "Ivory Coast: Ex-Combatants Seize Weapons and Takeover Former Rebel City", Africa News, January 6, 2017, http://www.africanews. com/2017/01/06/ivory-coast-ex-combatants-seize-weapons-and-tak eover-former-rebel-city/; "Bouaké et Man: Nouvelle manifestation d'excombattants qui réclament 18 millions," Abidjan.net, October 2, 2017, https://news.abidjan.net/h/623393.html.

36. Martin Ravallion, The Economics of Poverty-History, Measurement and Policy (New York: Oxford University Press, 2016).

37. Quoted in Ernest Harsch, "Reintegration of Ex-combatants: When War Ends: Transforming Africa's Fighters into Builders," Africa Renewal 1 (October 2005): 1 .

38. Victor Odame Asiedu, "From Combat to Community: A Study of how a Community-based Approach to Disarmament, Demobilisation, and Reintegration (DDR) can Contribute More Effectively to Peacebuilding: The Case of Sierra Leone," MPhil thesis, University of York, 2010.

39. Asiedu, "From Combat to Community," 2.

40. Ibid, 2.

41. Ibid.

42. Munive and Stepputat, "Rethinking Disarmament, Demobilization and Reintegration Programs."

43. See for instance: "Combatants on Foreign Soil," Issue Paper, Second International Conference on DDR in Africa, Kinshasa, Democratic Republic of the Congo, June 12-14, 2017, http://lekiworld.com/AU/ docs/150.pdf.

44. See https://unddr.com/.

45. See https://pdf.usaid.gov/pdf_docs/PNADF305.pdf.

46. "Community Based Reintegration and Security (CBRS) Specialised Training Course for Practitioners," Barcelona, Spain, June 21-28, 2015, http://unddr.org/DDR/training-event/community-based-reintegra tion-and-security-cbrs-specialised-training-course-for-_58.aspx; Barcelona International Peace Resource Centre and Transition International, "Community Based Reintegration and Security (CBRS): Specialized Training Course For Practitioners", June 21-28, 2015, Barcelona, Spain, http:// www.iddrtg.org/wp-content/uploads/2015/03/CBRS-Course-announ cement.pdf. 
47. Transition International, "Concept Note on Community Based (Re) Integration And Security (CBRS)," January 2015.

48. "Community Based Reintegration and Security (CBRS) Specialized Training Course for Practitioners," http://unddr.org/DDR/trainingevent/community-based-reintegration-and-security-cbrs-specialised-tra ining-course-for-_58.aspx. There was an advanced course scheduled in December 2018: Transition International and Barcelona International Peace Center, "(Re)Integration Advanced Training Course," Barcelona, Spain, December 14-21, 2018, https://www.transitioninternational. $\mathrm{com} / \mathrm{ti} /$ reintegration-training-course/.

49. United Nations, "Disarmament, Demobilization and Reintegration."

50. Ibid.

51. James Cockayne and Siobhan O'Neil (eds.), UN DDR in an Era of Violent Extremism: Is It Fit for Purpose? (Tokyo: United Nations University, 2015).

52. Verweijen and Wakenge, "Understanding Armed Group Proliferation in the Eastern Congo."

53. United Nations Development Programme (UNDP), Blame It on the War? The Gender Dimensions of Violence in Disarmament, Demobilization and Reintegration (UNDP: New York, 2012); United Nations Development Funds for Women (UNIFEM), Getting It Right, Doing It Right: Gender and Disarmament, Demobilization and Reintegration (New York: UNIFEM).

54. Maame Esi Eshun, "Skilling Africa's Informal Sector for Growth: The Role of Technical and Vocational Education and Training," Africa Up Close, Woodrow Wilson Center, June 11, 2018, https://africaupclose.wil soncenter.org/skilling-africas-informal-sector-for-growth-the-role-of-tec hnical-and-vocational-education-and-training/.

55. Katharina P. Coleman, The Dynamics of Peacekeeping Budget Cuts: The Case of MONUSCO (New York: International Peace Institute, July 10, 2017); "UN to Close Five Peacekeepers' Bases in Eastern DR Congo," The Independent, July 19, 2017.

56. African Union, "Disarmament Demobilization and Reintegration (DDR)," June 13, 2017, http://www.peaceau.org/en/page/68-disarm ament-demobilization-and-reintegration-DDR.

57. African Union, "Disarmament Demobilization and Reintegration (DDR)"; see also World Bank, Transitional Demobilization and Reintegration Quarterly Report, April-June 2014.

58. See also World Bank, Transitional Demobilization and Reintegration Program, "World Bank and UN DPKO Joint Support of the African Union DDR Capacity Program Brings Together DDR Training Experts and Stakeholders on DDR Compendium of Experiences and Training," 
June 10, 2015, http://www.tdrp.net/news_061015.php; World Bank, Transitional Demobilization and Reintegration Quarterly Report.

59. Antonio Guterres, Securing Our Common Future: An Agenda for Disarmament, United Nations, May 2018.

60. Such partnership is already a work in progress. See for instance: World Bank, "United Nations and World Bank leaders call for stronger international efforts to prevent violent conflict," Press Release, September 21, 2017, https://www.worldbank.org/en/news/press-release/2017/09/ 21 /united-nations-and-world-bank-leaders-call-for-stronger-internationalefforts-to-prevent-violent-conflict.

61. World Bank, "United Nations and World Bank leaders call for stronger international efforts to prevent violent conflict."

62. Antonio Guterres, Statement to the Security Council' Session on Peacebuilding and Sustaining Peace, April 25, 2018, https://www.un.org/sg/ en/content/sg/speeches/2018-04-25/peacebuilding-sustaining-peacebriefing-security-council.

63. Some of the regions in Africa that are the most affected by the threat posed by the multiplication of armed groups, including terrorist, and the proliferation of weapons are: the Great Lakes region, the Horn of Africa, the Sahel-Sahara band, and the Lake Chad basin, and the Mano River basin.

64. United Nations: HIPPO and SG's Agenda for Disarmament; World Bank, Pathways for Peace Inclusive Approaches to Preventing Violent Conflict Main Messages and Emerging Policy Directions (Washington, DC, 2017); and the African Union, "African Union Master Roadmap of Practical Steps to Silence the Guns in Africa by Year 2020."

65. United Nations: HIPPO and SG's Agenda for Disarmament; World Bank, Pathways for Peace; African Union, "African Union Master Roadmap."

66. See General Assembly, "Remarks to the General Assembly on the Secretary-General's Report on Peacebuilding and Sustaining Peace," March 5, 2018.

67. United Nations, "Disarmament, Demobilization and Reintegration."

68. United Nations, "A More Secure World: Our Shared Responsibility," Report of the High-Level Panel on Threats, Challenges and Change, A/59/565, December 2, 2004 (A/59565).

69. United Nations, "A more Secure World: Our Shared Responsibility."

70. "Decision on the African Union Master Roadmap of Practical Steps for Silencing the Guns in Africa by the Year 2020," African Union, TwentyEighth Ordinary Session of Heads of State and Government, January 31, 2017, Addis Ababa, Ethiopia, Assembly/AU/6 (XXVIII).

71. The World Bank has expressed its determination "to ensure that development programs and policies are focused on successful prevention." See World Bank, "United Nations and World Bank Leaders Call for 
Stronger International Efforts to Prevent Violent Conflict," Press Release, September 21, 2017.

72. The African Union 2030 Agenda for Sustainable Development, Goal 16: "We are determined to foster peaceful, just and inclusive societies which are free from fear and violence. There can be no sustainable development without peace and no peace without sustainable development."

73. Antonio Guterres, "Peacebuilding and Sustaining Peace," Report of the Secretary-General to the General Assembly and the Security Council, January 18, 2018, A/72/707-S/2018/43.

74. Sebastian von Eisendel, "Examining Major Recent Trends in Violent Conflict," United Nations University, Center for Policy Research, Occasional Paper 1, November 2014, https://i.unu.edu/media/cpr.unu.edu/ attachment/1558/OC_01-MajorRecentTrendsinViolentConflict.pdf.

Open Access This chapter is licensed under the terms of the Creative Commons Attribution 4.0 International License (http://creativecommons.org/licenses/ by $/ 4.0 /$ ), which permits use, sharing, adaptation, distribution and reproduction in any medium or format, as long as you give appropriate credit to the original author(s) and the source, provide a link to the Creative Commons license and indicate if changes were made.

The images or other third party material in this chapter are included in the chapter's Creative Commons license, unless indicated otherwise in a credit line to the material. If material is not included in the chapter's Creative Commons license and your intended use is not permitted by statutory regulation or exceeds the permitted use, you will need to obtain permission directly from the copyright holder.

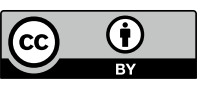

